\title{
Guava Fruit Fly, Bactrocera correcta (Bezzi) (Insecta: Diptera: Tephritidae) ${ }^{1}$
}

Howard W. Weems, Jr. and T. R. Fasulo ${ }^{2}$

\section{Introduction}

Bactrocera correcta (Bezzi), often referred to as the "guava fruit fly" (although the larvae of many other species of fruit flies feed on guava - and Anastrepha striata Schiner is also called the "guava fruit fly") (White and Elson-Harris 1994), was detected for the first time in the Western Hemisphere when one female was found on August 6, 1986 in Garden Grove, Orange County, California. Two additional adult males were detected in Orange County on August 9, 1986. B. correcta has been detected numerous times in California since then, but has not become established.

A single adult male was captured in a fruit fly detection trap in Oviedo, FL, on July 30, 2001. Another male was trapped in Apopka (Orange County, Florida) on 4 May 2001. This is only the third and fourth such incidence of this species in Florida as two flies were captured in the Titusville area (Brevard County) in August, 1999. If an infestation were to go unchecked and to become established in U.S. areas such as California or Florida, B. correcta has the potential to become a major pest of citrus, peach and several kinds of tropical and subtropical fruit hosts.

\section{Synonymy}

Bactrocera correcta (Bezzi) has also been known as:

Chaetodacus correctus Bezzi,

Dacus (Strumeta) correctus (Bezzi)

Bactrocera zonata Bezzi

\section{Distribution}

Bactrocera correcta occurs in India, Pakistan, Nepal, Sri Lanka, and Thailand.

\section{Identification}

Bactrocera correcta is a brightly colored little fly, predominately black with lateral yellow stripes, approximately $5.4 \mathrm{~mm}$ in length. In his original description of B. correcta (as Chaetodacus correctus, Bezzi (1915)) stated that B. correcta was very near $D$. zonatus (now Bactrocera zonata (Saunders) - the

1. This document is EENY-200 (originally published as DPI Entomology Circular No. 291), one of a series of Featured Creatures from the Entomology and Nematology Department, Florida Cooperative Extension Service, Institute of Food and Agricultural Sciences, University of Florida. Published: March 2001. Revised: May 2001, October 2002. This document is also available on Featured Creatures Website at http://creatures.ifas.ufl.edu. Please visit the EDIS Website at http://edis.ifas.ufl.edu.

2. Howard W. Weems, Jr., Florida Department of Agriculture and Consumer Services, Division of Plant Industry, and T.R. Fasulo, Entomology and Nematology Department, Cooperative Extension Service, University of Florida, Gainesville, FL.

The Institute of Food and Agricultural Sciences (IFAS) is an Equal Employment Opportunity - Affirmative Action Employer authorized to provide research, educational information and other services only to individuals and institutions that function without regard to race, creed, color, religion, age, disability, sex, sexual orientation, marital status, national origin, political opinions or affiliations. For information on obtaining other extension publications, contact your county Cooperative Extension Service office. Florida Cooperative Extension Service / Institute of Food and Agricultural Sciences / University of Florida / Larry R. Arrington, Interim Dean 
peach fruitfly), but it is distinguished by the color of the thorax, and chiefly by the facial black spots being united to form a black transverse band; the whitish cross-band on the second abdominal segment is less developed, and the hind tibiae of the male are distinctly tuberculate before the end, similar to that of two closely related species, $B$. zonata (previously $D$. zonatus) and $B$. tuberculata (Bezzi) (previously $D$. tuberculatus).

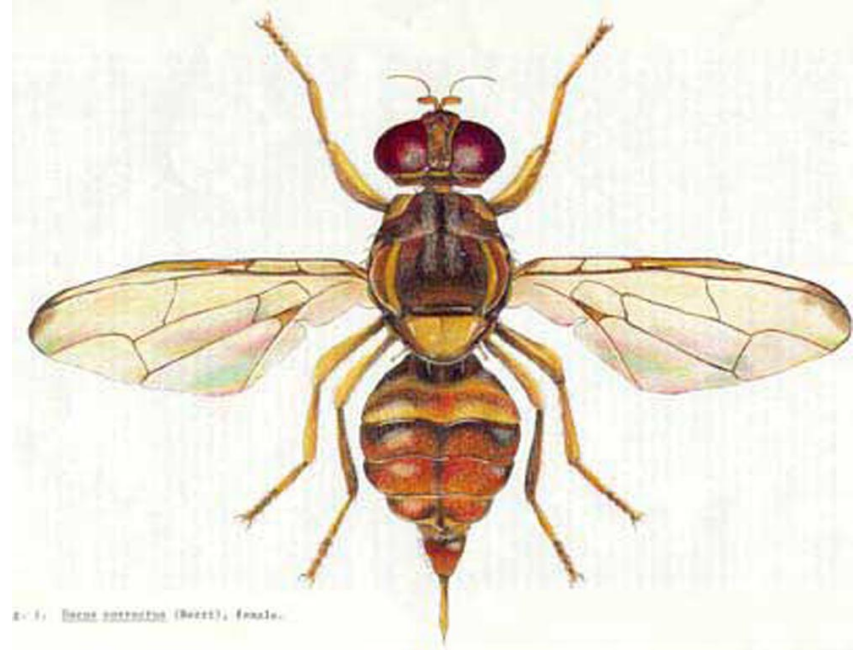

Figure 1. Adult female guava fruit fly, Bactrocera correcta (Bezzi). Credits: Division of Plant Industry

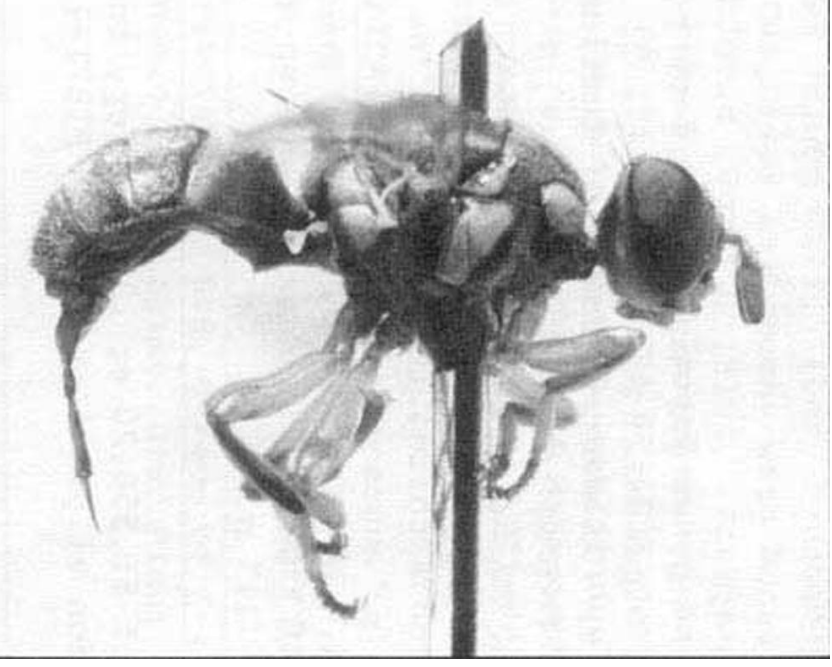

Figure 2. Lateral view of an adult female guava fruit fly, Bactrocera correcta (Bezzi), showing ovipositor sheath and fully extended ovipositor. Credits: Division of Plant Industry

In his redescription of Bactrocera correcta (as $D$. correctus), Hardy (1973) noted the close relationship of this species with $B$. zonata and that the wing markings and morphological details are similar in the

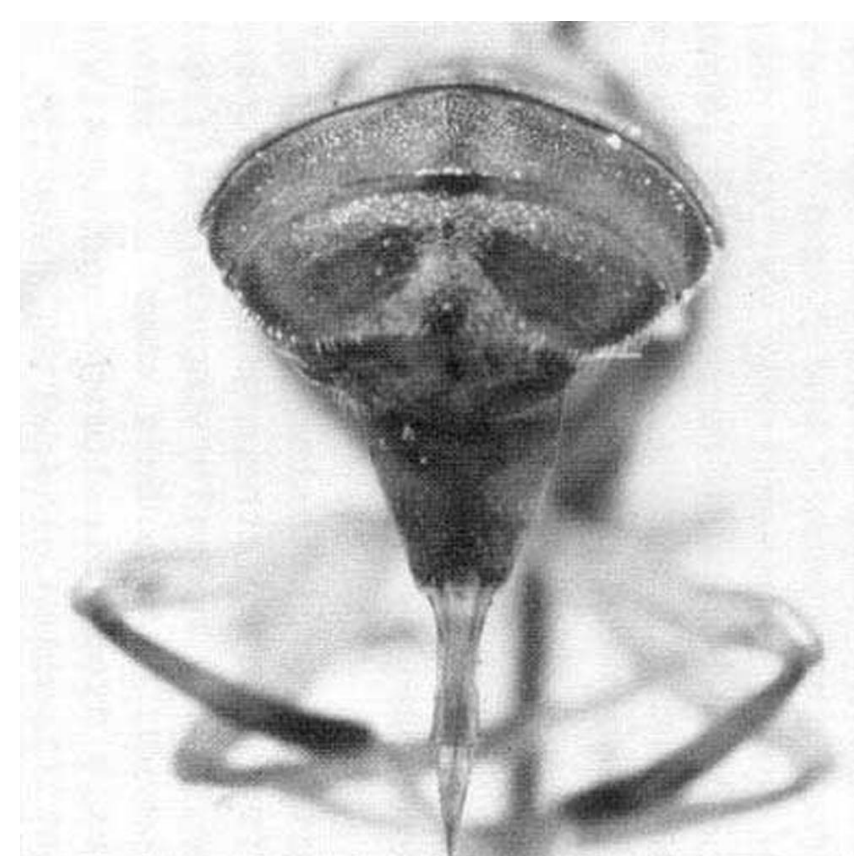

Figure 3. Caudal view of an adult female guava fruit fly, Bactrocera correcta (Bezzi), showing ovipositor sheath and fully extended ovipositor. Credits: Division of Plant Industry

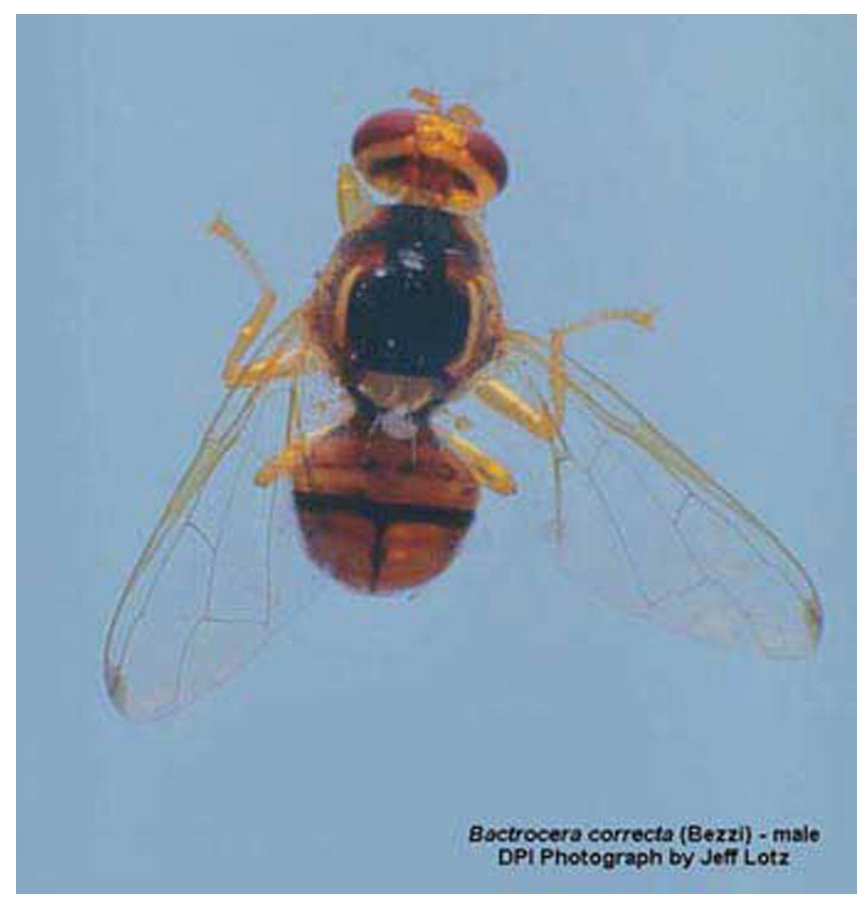

Figure 4. Adult male guava fruit fly, Bactrocera correcta (Bezzi). This is the actual fly captured in Apopka, Florida on May 4, 2001. Credits: Jeff Lotz, Division of Plant Industry

two. He indicated that $B$. correcta is readily differentiated by having the mesonotum predominantly black through the median portion of the mesonotum, covered with gray pubescence and with three rather indistinct subshining black, narrow vittae, rather than rufous; and usually by having a 
complete transverse band in the furrow across the lower part of the face, rather than the usual two black facial spots of related species. This marking sometimes is interrupted in the median portion, but in fully hardened specimens it appears to be complete at least as a narrow brown to black line. However, George Steyskal, in his letter dated 26 August 1986, observed that specimens in the (U.S.) National Museum of Natural History collection, all identified by Hardy, show distinct interruption of the two facial bars.

\section{Hardy (1973) stated that B. correcta is} differentiated from other species known from Thailand and surrounding regions by having the face with the black transverse band at the lower third and by having the costal end of the wing interrupted in cell R3, beyond the tip of vein R2+3. Wings are almost entirely hyaline with the subcostal cell yellow, a very faint tinge of yellow along the costal margin in apex of cell R1, and a narrow brown spot at lower apex of cell R3 and upper apex of cell R5. Cubital cell faintly yellow and no cubital streak developed. Abdomen rufous above except for black basal marks on terga 2 and 3 and a median black vitta from terga 3 over 5. Sterna of both sexes entirely yellow. Legs mostly yellow.

Ovipositor of female red, rather short, measuring approximately $3.0 \mathrm{~mm}$ when fully extended. Basal segment short, approximately equal in length to terga 5-6 and about $0.8 \mathrm{~mm}$ long. Piercer gradually tapered to a short point, about $1.0 \mathrm{~mm}$ in length.

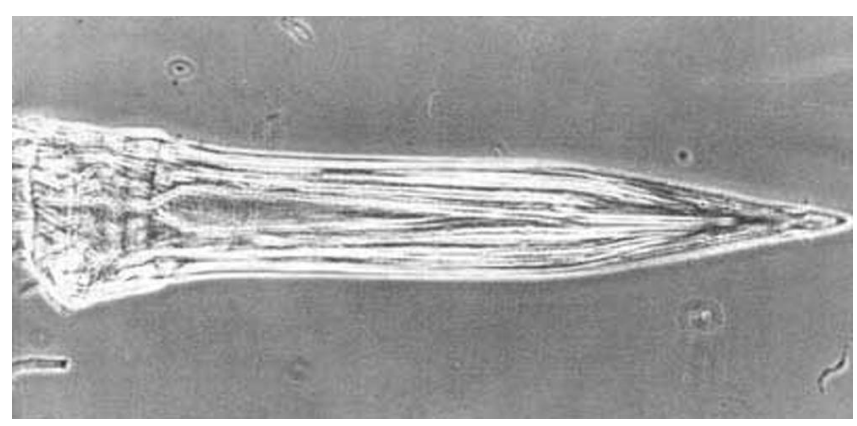

Figure 5. Ovipositor of an adult female guava fruit fly, Bactrocera correcta (Bezzi). Credits: Division of Plant Industry

Immature stages of $B$. correcta have not been described in the literature, and specimens were

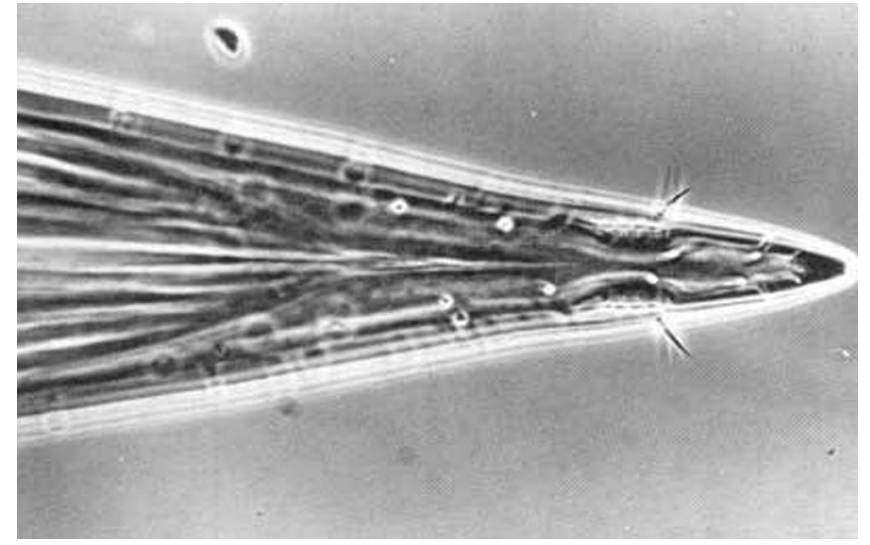

Figure 6. Ovipositor tip of an adult female guava fruit fly, Bactrocera correcta (Bezzi). Credits: Division of Plant Industry

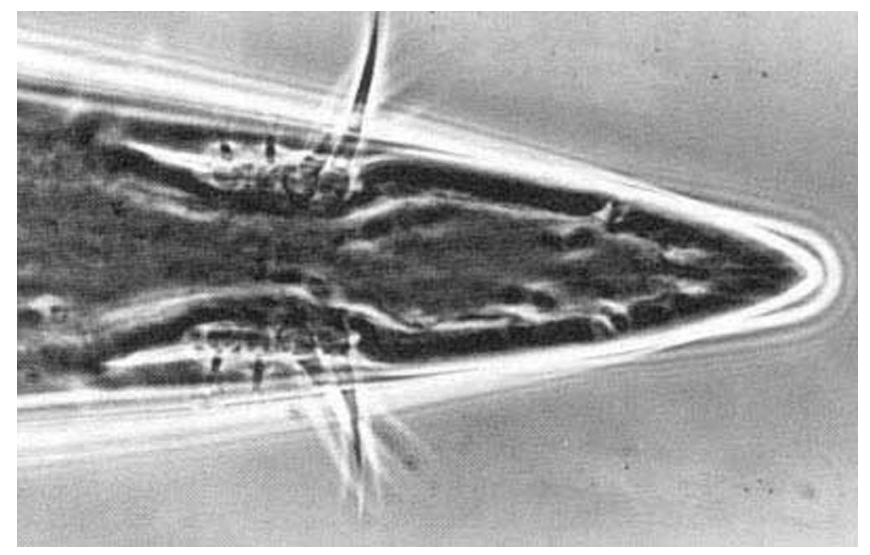

Figure 7. Closeup of ovipositor tip of an adult female guava fruit fly, Bactrocera correcta (Bezzi). Credits: Division of Plant Industry

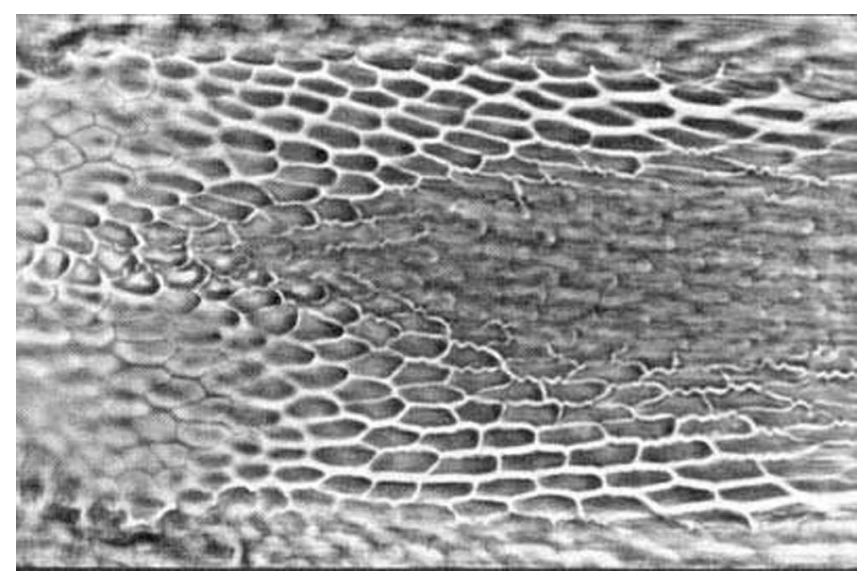

Figure 8. Microreticulation near base of the ovipositor of an adult female guava fruit fly, Bactrocera correcta (Bezzi). Credits: Division of Plant Industry

unavailable to the senior author from which to prepare descriptions. 


\section{Hosts}

Recorded hosts include Citrus spp., Coffea canephora Pierre ex Froehn. (as Coffea robusta), Eugenia uniflora L. (as Eugenia mitchelli), Mangifera indica L. (mango), Prunus persica (L.) Batsch (peach), Psidium guajava L. (guava), Ricinus communis L. (castor bean, castor-oil-plant, palma christi, wonder tree), Santalum album L. (sandalwood, white sandalwood), Syzygium jambos (L.) Alston (as Eugenia jambos) (roseapple), and Ziziphus spp., including Ziziphus jujuba Mill. (ber, jujube, Chinese date).

Bezzi (1915) noted that $B$. correcta lives in company with B. zonata (W.W. Saunders, 1841) and $B$. tuberculata (Bezzi, 1915), feeding on the same fruits. B. zonata, in India called "the Ranchi peach-pest," is very injurious to peach, mango, and several other fruits, including ripe Aegle marmelos (L.) Correa (Bael fruit), Careya arborea Roxb., Ficus carica L. (cultivated fig, common fig, lemon fig), Lagenaria vulgaris (white gourd), and Manilkara zapota (L.) Van Royen (as Achras sapota) (sapodilla), all of which must be considered potential hosts of B. correcta.

\section{Survey and Detection}

The adult female detected in California was found in a methyl eugenol-baited Jackson trap. Of the two additional adult males detected, one was trapped in a Jackson/methyl eugenol trap hung in a peach tree in Westminster, the other in a Jackson/methyl eugenol trap deployed in a grapefruit tree in Midway City. Trap density in the area of the original finds was five traps per square mile. California Department of Food and Agriculture Pest Detection/Emergency Projects personnel responded promptly by deploying Jackson/methyl eugenol and McPhail traps at 50 traps in the epicenter miles. Trapping in the surrounding 80 square miles was increased to five Jackson/methyl eugenol traps per square mile.

In India, males were found to be attracted to tulsi plant (Ocimum sanctum) which yields aromatic oils, $40 \%$ of which are methyl eugenol.

Larvae can be collected from infested fruit, killed in boiling water, and placed in 50\% alcohol for two days, then to $75 \%$ isopropyl alcohol, but specific identification based solely upon larvae is difficult. Larvae of many species of fruit flies are unknown. An effort should be made to rear some larvae to adults in order to correctly associate larvae and adults and provide the basis for accurate specific identification. Adults usually are collected by use of stickyboard and baited traps.

\section{Selected References}

Bezzi, M. 1915. On the fruit-flies of the genus Dacus (s. 1.) occurring in India, Burma, and Ceylon. Bull. Ent. Res. 7: 99-121.

Hardy, D.E. 1973. The fruit flies (Tephritidae--Diptera) of Thailand and bordering countries. Pacific Insects Monograph 31: 1-353.

Hardy, D.E. 1977. Family Tephritidae, p. 44-134. In: Delfinado, M.D., and D.E. Hardy (eds.), A catalog of the Diptera of the Oriental Region. Vol. III. Suborder Cyclorrhapha (excluding Division Aschiza). i-x +854 p. The University Press of Hawaii, Honolulu.

Kapoor, V.C., D.E. Hardy, M.L. Agarwal, and J.S. Grewal. 1980. Fruit fly (Diptera: Tephritide) systematics of the Indian subcontinent. Export India Publications. Jallundur, India. $111 \mathrm{p}$.

Steck, G.J. (13 August 2002). A guava fruit fly, Bactrocera correcta (Bezzi) (Tephritidae). Pest Alert.

http://www.doacs.state.fl.us/ pi/enpp/ento/ bcorrecta.html (1 October 2002).

White, I.M., and M.M. Elson-Harris. 1994. Fruit Flies of Economic Significance: Their Identification and Bionomics. CAB International. Oxon, UK. 601 p. 